\title{
IMMEDIATE ENDOCRINE AND METABOLIC CONSEQUENCES OF TRAUMATIC QUADRIPLEGIA IN A YOUNG WOMAN
}

\author{
By Jacqueline Claus-Walker, Ph.D., ${ }^{1}$ R. E. Carter, M.D., ${ }^{1}$ \\ Nicola M. Di Ferrante, M.D., Ph.D. ${ }^{2}$ and Jagat Singh, Ph.D. ${ }^{3}$ \\ ${ }^{1}$ Department of Rehabilitation; ${ }^{2}$ Department of Biochemistry, Baylor College of Medicine; \\ ${ }^{3}$ Laboratory Service; Veterans Administration Hospital, Houston, Texas 77030, U.S.A.
}

\section{Introduction}

THE immediate endocrine and metabolic response to the complete functional transection of the cervical spinal cord in humans should be clarified to achieve optimal emergency care. What happens at onset may help to find the aetiology of the numerous complications occurring in quadriplegic patients. To the best of our knowledge, the following presents the first such patient study.

\section{Case Presentation}

At I3 5 hours on I9 May I976, a I6 $\frac{1}{2}$-year-old, chubby girl (I.52 metres tall, $72 \mathrm{~kg}$ in weight) dived into shallow water, hit bottom, and was immediately rendered quadriplegic. She was taken to a neighbourhood clinic where radiologic examination revealed a fracture of the body of the 6th cervical vertebrae. A catheter was inserted into her bladder; and an intravenous drip, started at about I 400 hours, was continued while the patient was in the ambulance. She arrived at Texas Institute for Rehabilitation and Research at I700 hours. The urine excreted from onset and a blood sample were collected upon arrival. Subsequently, the neurosurgeon inserted tongs in her skull for cervical traction. Thereafter, urine samples were analysed every 4 hours for the first 24 hours after the injury and for the next 4 days, and blood samples were taken on 20, 2I, and 24 May at $0800 \mathrm{~h}$.

The patient was given 2.6 litres of IV dextrose in $\frac{1}{2}$ strength saline and $\frac{1}{4}$ strength saline from onset to I 200 hours the following day (I9, 20 May), I.9 litres from I 200 to I 200 hours on the 2 nd day (20, 2I May) and 0.5 litres from I 200 to 1900 hours on the 3 rd day (2 I May). She had no oral intake for I6 hours post injury; subsequently her oral fluid intake was (in litres): 0.57 on day I; 2.9 on day 2; 4.0 on day $3 ; 5.0$ on days 4 and 5 . The patient received the routine care given to spinal cord injured patients: she had $\mathrm{I} 0 \mathrm{lb}$ traction and her legs were elevated $15^{\circ}$. She was given one positive pressure breath for I2-I 5 deep breaths four times a day. The bladder was drained with an indwelling Foley catheter and her bowels were emptied with enemas. She was given dexamethasone, $20 \mathrm{mg}$ the day of onset, I $5 \mathrm{mg}$ the following days. In addition, she was given acetylsalicylic acid for headache on day I. On day 2 she was given pentazocine (Talwin ${ }^{(\mathrm{R})}$ ) for pain,

Supported by grant from the Department of Health, Education and Welfare, RSA I6-P-56813/6, and grant from the Schlumberger Foundation, Houston, Texas, U.S.A.

Supported by grant USPH I8692-OI and by Zyma, S. A., Nyon, Switzerland.

Address for reprints: Jacqueline Claus-Walker, Ph.D., Texas Institute for Rehabilitation and Research, 1333 Moursund, Houston, Texas 77030, U.S.A. 
I20 mg; methenamine mandelate (Mandelamine $\left.{ }^{(\mathrm{R})}\right) 4 \mathrm{~g}$, to prevent urinary infection; and $\mathrm{I} 80 \mathrm{ml}$ of a mixture of magnesium trisilicate and aluminium hydroxide (Gelusil ${ }^{(\mathrm{R})}$ ) for gastric acidity. On days 3,4 , and 5 , the patient had the same medication, except for pentazocine ( $180 \mathrm{mg}$ on day $3 ; 60 \mathrm{mg}$ on day 4 ; discontinued, day 5). She was given one capsule of methylpryton (Noludar ${ }^{(\mathrm{R})}$ ) for sleep on day 5 .

\section{Laboratory Methods}

Urine and serum phosphorus was measured by the method of Fiske and Subbarrow (1925), urine and serum calcium by atomic absorption photometry, urine and serum electrolytes by flame photometry (Instrumentation Laboratory Model I43). Hydroxyproline was evaluated according to Kivirikko et al. (1967). High molecular weight peptide bound hydroxyproline was measured according to Krane et al. (1970). Hydroxylysine glycosides were evaluated by the method of Askenasi (1975).

Plasma renin activity and serum parathyroid hormone were evaluated by radioimmunoassays, using the methods of Haber (1969) and Scurry (1975) respectively.

Plasma cortisol and urine cyclic adenosine $3^{\prime} 5^{\prime}$ monophosphate were evaluated by protein binding assays, according to the method of Murphy (1967) and Steiner (1972).

Urine I7 hydroxycorticosteroid was evaluated by the chemical method of Glenn and Nelson (1953). Twenty per cent of the value was subtracted to correct for dexamethasone intake.

Balances were calculated by subtracting the intake (oral and intravenous) from the urine output.

\section{Results}

The temporal sequence of abnormal amounts of bone and collagen metabolites appearing in the urine is shown in Figure I. Only glucosyl-galactosyl-hydroxylysine increased on day I (43 per cent above normal). Galactosyl-hydroxylysine, hydroxyproline, and phosphorus were 36 per cent, I i 8 per cent, and 70 per cent above normal on day 2 ; calcium and high molecular weight peptide bound hydroxyproline were I 20 per cent and 70 per cent above normal on day 4 .

Supine plasma renin activity was slightly increased once at 20 hours post onset. Serum phosphorus, calcium, sodium, and potassium were normal. Plasma cortisol was very high only in the sample taken 4 hours after onset. Seventeen hydroxycorticosteroids were high in the initial 4 hours urine sample and kept increasing until 20 hours had elapsed; it was low afterwards (Figure 2.)

Serum parathyroid hormone was below measurable concentration (less than $25 \mu \mathrm{lEq} / \mathrm{ml}$ ) on days $\mathrm{I}, 2,4$; and $40 \mu \mathrm{lEq}$ on day 5 . Urine cyclic adenosine $3^{\prime} 5^{\prime}$ monophosphate was above normal on day 2, and was 95 per cent above normal on day 4. The fluid balance was positive for 3 days, and became negative on day 4 and 5 and also afterwards. The potassium balance was negative on days 3,4 , and 5 . The sodium balance was positive and became strongly negative on days 3,4 , and 5 (Figure 2).

\section{Discussion}

The elevated cortisol at 4 hours may or may not represent overriding of suppressive effect of dexamethasone on ACTH. Since it is so near time zero, and since it takes a while for suppression anyhow, and since half-time of cortisol is 60-90 minutes, probably one should have had more values between 4 and 24 hours. 

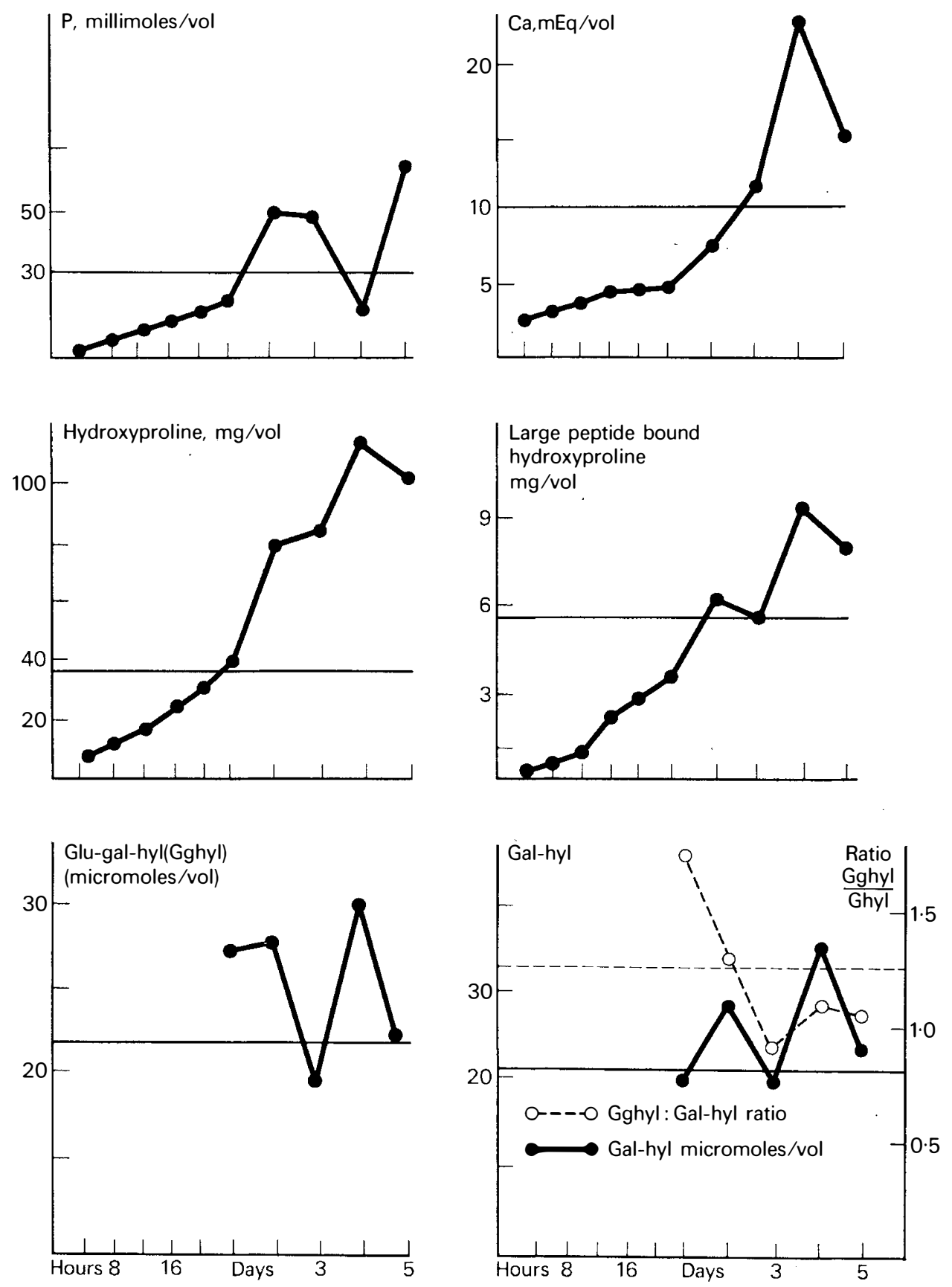

FIG. I

Urine excretion of collagen and bone metabolites during the initial 5 days of quadriplegia (normal values indicated by horizontal straight line). 

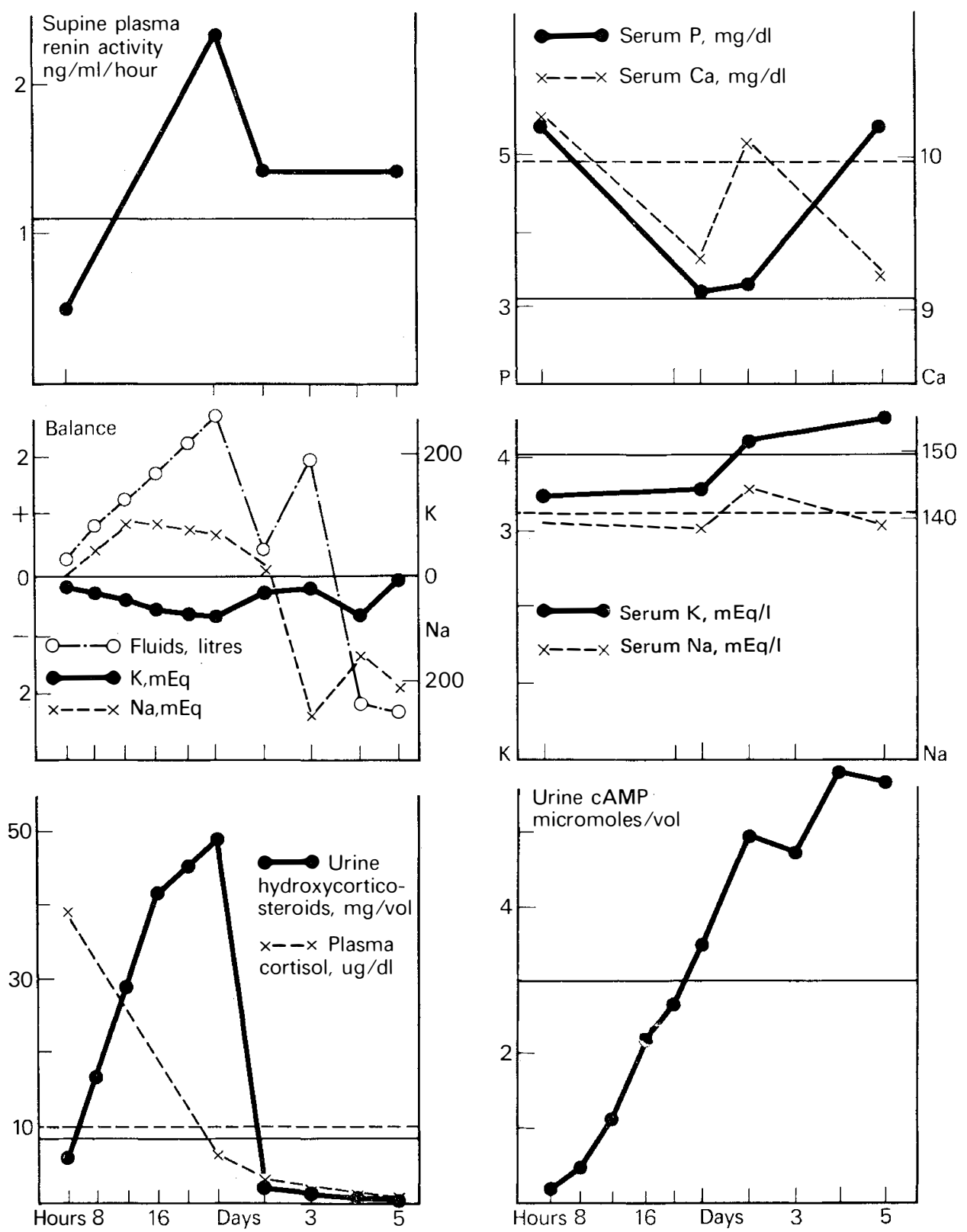

FIG. 2

Blood hormones and urine metabolites during the initial 5 days of quadriplegia (normal values indicated by horizontal straight line). 
Urinary excretion of I 7 hydroxycorticosteroids suggests that there was continued ACTH release for at least 12 hours. The subsequent low values of 17 hydroxycorticosteroids in urine and cortisol in blood represent dexamethasone suppression. The results indicate that dexamethasone therapy may be delayed for a few hours, and perhaps a full day. This gives a scientific basis to the empirical findings that a spinal cord injured patient will be able to undergo surgery well on the 2 initial days after the trauma, but not for a while thereafter.

In this patient, several changes occurred with a definite sequence indicating that functional transection of the cervical spinal cord leads to an alteration in the metabolism of collagen. Glycosyl-galactosyl-hydroxylysine, a most abundant component of skin collagen (Askenasi, 1975), was increased in the urine within 24 hours after the trauma. Galactosyl-hydroxylysine, present predominantly in bone collagen, and total hydroxyproline, a constituent of all collagens, were increased in the urine within 48 hours after the injury, and the ratio glucosylgalactosyl to galactosyl-hydroxylysine decreased. This may have been related to the cervical fracture, although the increase was smaller than the one seen 4 days after spinal fusion of scoliotic patients (Lou \& Hamilton, I97I). Bone minerals in urine increased also: phosphorus, within 48 hours, and calcium, only after 96 hours. At this time the peptide bound hydroxyproline also increased, indicating an activation in collagen synthesis (Krane et al., 1970). This trend for hydroxyproline, $\mathrm{P}$, and $\mathrm{Ca}$ excretion was found earlier in a larger group (Claus-Walker et al., 1975). The cause for the increase in urinary bone metabolites was not a measurable increase in parathyroid hormone. This is further substantiated by finding only a small cAMP increase in urine, very different from the 13 -fold increase in I hour during infusion of 50 units/hour of PTH (Weber et al., I975) and may only reflect increased catabolism due to the initial stress and to spinal cord trauma (ClausWalker et al., 197I). The effects of recumbency and paralysis upon the fluid and electrolytes distribution, and their role in the aetiology of the bone changes, has been debated by Griffith (I97I). In the patient studied, the balance of fluid and electrolytes was already abnormal on the 4 th day, when the calciuria started upward; the cumulative fluid balance 13 days after the trauma was -32 litres and the patient lost I I kilos ( $72 \mathrm{~kg}$ to $6 \mathrm{I} \mathrm{kg}$ ). The urine specific gravity was low on day 5 ( $\mathrm{I} \cdot 004)$. She continued to have negative fluid balance for a month after injury ( -38 litres total) but her weight was stable. During the period of fluid loss, the patient had an inappropriate fall in the haematocrit: from $39 \mathrm{~mm}$ at onset, it fell to 36 in 14 days, and to $34 \mathrm{~mm}$ in $\mathrm{I}$ month. This and the decrease in creatinine excretion, from $\mathrm{I} \cdot 509$ to 0.86 in 25 days, suggests that water was lost from all body compartments, including muscle mass. Previous studies have indicated that head up tilt and physical therapy minimise the duration, but not the amplitude, at a given time, of the bone changes. Hypothetically, the circulatory adjustment occurring in early quadriplegia, leading to permanent changes in body composition (Cardus et al., I969). are accelerated by tilt and wheelchair activities, which help to reach a new equilibrium earlier. Then the bone metabolism will remain stable as long as the patient keeps active, until 5 years has elapsed, as it has been shown that the maximum osteoporosis is reached at this time (Griffiths et al., 1972). These years may be the most important for the patient to keep up his activities.

Another point of interest was that in this patient the spinal cord injury had no effect upon menstrual flow, which occurred at the expected date.

This limited study, and previous data (Claus-Walker et al., 1976) indicate that there is no specific hormone activation directly responsible for the collagen and bone related metabolic consequences of quadriplegia, and therefore no specific 
treatment. The ongoing changes in the size of the relative body compartments for water and electrolytes may be involved, and the continuing studies should include their evaluation. The results also indicate that trauma to the cervical spinal cord elicits a short-lived normal adrenocortical response.

\section{SUMMARY}

Onset of paralysis by cervical spinal cord injury led immediately to temporary adrenocortical activation and, within 2 days, to sustained skin and bone breakdown. Urine cAMP was increased, blood parathyroid hormone, renin activity, and electrolytes were normal, and fluid and electrolytes balance became negative during the initial 6 days of paralysis.

\section{RÉSUMÉ}

La tétraplegie, due une insulte de la moelle épiniere cervicale, est immédiatement suivit par une activation éphemère du cortex surrenalien. Le catabolisme de longue durée de la peau et des os, s'observe après 2 jours. Pendant les 6 premiers jours, on trouve une faible augmentation du monophosphate cyclique d'adénosine, mais pas de changements d'hormone parathyroidienne, de rénine et d'electrolytes sanguins. Le bilan des liquides et électrolytes urinaires devient négatif durant cette période.

\section{ZUSAMMENFASSUNG}

Paralyse in Rückenmarksverletzung des Zervicalmarks führt sofort zur vorübergehende adrencorticale Aktivierung und innerhalb von zwei Tagen zum Zusammenbruch von Hautund Knochen. Urin cAMP war vermehrt, Blut-parathyroid Hormon, Reninaktroität und Elektrolyte waren normal, während Flüssigkeit und Electrolyt Sleichgewicht wurden während der ersten 6 Tage der Lähnung negativ.

Acknowledgements. We want to acknowledge the participation in this project of Paul S. Sharkey, M.D., neurosurgeon, and Lida S. Dahm, M.D., anaesthesiologist, Department of Rehabilitation; Bruce Keenan, M.D., who performed the steroid assay, Department of Pediatrics; all from Baylor College of Medicine. A. B. Chausmer, M.D., who performed the parathyroid hormone assay, Department of Medicine, University of Texas Medical Branch, Galveston; Merrill Overturf, Ph.D., who performed the renin assay, Department of Internal Medicine, and G. Alan Robinson, Ph.D., Professor and Chairman, Department of Pharmacology, University of Texas Medical School at Houston, who measured cyclic AMP.

We also wish to acknowledge the technical assistance of Gladys Rodriguez, B.S., and Carolyn Hubert, M.T., A.S.C.P., Department of Rehabilitation, Baylor College of Medicine.

\section{REFERENCES}

AsKenASI, R. (1975). Urinary excretion of free hydroxylysine, peptide-bound hydroxylysine and hydroxylysyl glycosides in physiological conditions. Clin. Chem. Acta, 59, 87-92.

Cardus, D., Spencer, W. A. \& McTagGart, W. G. (1969). A study of the gross composition of the body of patients with extensive muscular paralysis. Social and Rehabilitation Project RD-I87I-M, Final Report.

Claus-Walker, J., Scurry, M., Carter, R. E. \& Campos, R. J. (1977). Steady state hormonal secretion in traumatic quadriplegia. Fournal of Clinical Endocrinology and Metabolism., 44, 530-535.

Claus-Walker, J., Spencer, W. A., Carter, R. E., Halstead, L. S., Meier III, R. H. \& CAMPOS, R. J. (I975). Bone metabolism in quadriplegia: dissociation between calciuria and hydroxyprolinuria. Arch. Phys. Med. Rehabil. 56, 327-332.

Claus-Walker, J., Vallbona, C., CARTER, R. E., \& LipsComb, H. S. (I97I). Resting and stimulated endocrine function in human subjects with cervical spinal cord transection. f. Chron. Dis. 24, 193-207. 
Fiske, C. H. \& SubBarrow, Y. (I925). The colorimetric determination of phosphorus. F. biol. Chem. 66, 375-400.

GlenN, E. M. \& NELSON, D. H. (1953). Chemical method for the determination of 17-hydroxy-corticosteroids and 17-ketosteroids in urine following hydrolysis with B-glucuronidase. f. Clin. Endocrinol. Metab. 13, 91 I.

GRIFFITH, D. P. (I97I). Immobilization hypercalciuria: treatment and a possible pathophysiologic mechanism. Aerospace Medicine, 42, I322-1324.

Griffiths, H. J., D'Orsi, C. J. \& Zimmerman, R. E. (I972). Use of ${ }^{125}$ I photon scanning in the evaluation of bone density in a group of patients with spinal cord injury. Investigative Radiology, 7, 107-I I 7 .

Haber, E., Koerner, T., Page, L. B., Kliman, B. \& Purnode, A. (1969). Application of a radioimmunoassay for angiotensin I to the physiologic measurements of plasma renin activity in normal human subjects. F. Clin. Endocrinol. Metab. 29, I349-1355.

Kivirikko, K. I., Laitinen, O. \& Prockop, D. J. (I967). Modifications of a specific assay for hydroxyproline in urine. Anal. Biochem. 19, 249-255.

Krane, S. M., Munoz, A. J. \& Harris E. D., Jr. (I970). Urinary polypeptides related to collagen synthesis. F. Clin. Invest. 49, 7 16-729.

Lou, M. F. \& Hamilton, P. B. (I97I). Hydroxylysine glycosides in human urine. Clin. Chem. 17, 782-788.

Murphy, B. E. P. (1967). Some studies of the protein-binding of steroids and their application to the routine micro and ultramicro measurement of various steroids in body fluids by competitive protein-binding radioassay. F. Clin. Endocrinol. Metab. 27, 973-990.

SCURRY, M. T. (I 975 ). Serum parathyroid hormone: a double antibody radioimmunoassay. Texas Rep. Biol. Med. 33, 457-464.

Steiner, A. L., WehmanN, R. E., Parker, C. W. \& Kipnis, D. M. (I972). Radioimmunoassay for the measurement of cyclic nucleotides. Adv. Cyclic. Nucleotide Res. 2, 5I-61.

Weber, M. A., KleErekoper M., Thornell I. R. \& Stokes, G. S. (I975). Effects of sodium depletion on plasma renin activity and on the urinary excretion of cyclic AMP and aldosterone in hypoparathyroid patients. F. Clin. Endocrinol. Metab. 40, 982-987. 